\title{
Impact Assessment of Classroom-Based Artificial Intelligence in Bulacan Agricultural State College
}

\author{
Kristine C. Buenaventura, Ma. Melanie Ablaza-Cruz
}

\begin{abstract}
The study aims to give a comprehensive report on findings on managing the BASC computer laboratory classroom by using assisted learning technology. The study implemented and assessed the output of the capstone project of the BSIT students entitled "Intelligent Personal Assistant via Speech Recognition". The researcher conducted a systematic review of the performance of the system in terms of its procedure in manipulating the different applications installed in each computer laboratory. This includes the current management in the different facilities and application in every workstation. The researcher also observed the performance of the system and investigate the advantages of this technology which helps the instructor on handling the classroom laboratory. This study helps the institution to improve its services to its clientele to be more globally competitive. The study would like to seek for more possible application and implementation of Artificial Intelligence System in the Bulacan Agricultural State College in order to maximize the usage of the study.
\end{abstract}

Keywords: Artificial Intelligence, Assessment, Classroom Management, Voice Recognition

\section{INTRODUCTION}

With the continuous advancement of information technology today, computers have been essential as teaching tools in education (Ji, 2015). Moreover, computer laboratory is vital not only in Information and Communication Technology courses; also, it is equally important to different allied courses as well. The Bulacan Agricultural State College is offering a various course, the institute of engineering and applied technology under this college was handling different computer subject. Hence, this institute was assigned to maintain the different computer laboratory classroom in the college. However, not only teaching business was being conducted in every computer laboratory, sometimes this room was also used for institute meetings, and training. Meanwhile, the other courses with large number of students are also using the laboratory for lecture and examination activities.

Specialized course teaching and basic course teaching mostly rely on the same computer laboratory classroom, this means that every classroom laboratory was open to every students which makes it more difficult to manage. The person in-charge in every laboratory room, was not only a laboratory custodian but also an instructor as well. Additionally, the

Revised Version Manuscript Received on 10 September, 2019.

Kristine C. Buenaventura, Institute of Engineering and Applied Technology, Bulacan Agricultural State College, Bulacan, Philippines. (Email: kristinecruz110913@gmail.com)

Ma. Melanie Ablaza-Cruz, Institute of Engineering and Applied Technology, Bulacan Agricultural State College, Bulacan, Philippines. (Email: melanieablazacruz@gmail.com) number of computer available in every laboratory classroom was not enough because the number of students is higher than

the computer units. This scenario was not new in every semester, as a solution to this problem; every class was usually group into two (2) or three (3) batch per session. In every laboratory class, three (3) hours was allotted in every section, which means that when this class was group the time allotted for their laboratory class was already lessen. Another concern in this situation was the time in preparation of every computer units in every class was time consuming, also, the individual assessment and checking of every student activity after every batch will also consume the time. Considering the above factors, management in every classroom laboratory is not easy.

However, Artificial Intelligence has been applied in the education sector, and universities come to adopt this technology because of its effects on this advancement in today's classroom settings. Additionally, due to the latest improvements in computer technology and speech recognition algorithms, speech recognition machines have begun to appear and have become increasingly more powerful and less expensive. This situation leads the development of the Intelligent Personal Assistant via Speech Recognition system. This is to address issues concerning with laboratory classroom management. This was designed to help the instructor to minimize the time consume in every laboratory class and to easily manage the computer laboratory.

Simultaneously, system was able to turn on and turn off the light and electric fan by using voice command recognition. The instructor can also use the system to open and close the software application used by every student through voice command recognition. This paper aims to assess the acceptability of the Intelligent Personal Assistant technology in managing the classroom laboratory, to address the main problem which is to lessen the time consumes in managing the laboratory class. The researcher conducted a systematic review of the performance of the system in terms of its functionality in manipulating the different applications installed in computer laboratory. This includes the current management in the different facilities and software installed such as applications software in every workstation.

The performance of the system features such as the procedures of the speech recognition technology in receiving and executing commands from the user have been observed. The study would like to assess the system to 
seek for a more possible solution in managing the classroom setup. The study will help to minimize the problem regarding the management of the laboratory classroom in BASC. The Lack of computers in every laboratory room, time management in every laboratory exercises and activities was also be considered.

\section{METHODOLOGY}

An approval from the developer of the system was sought before conducting the study. After the approval, the researcher examined the artificial intelligence system by integrating the student's capstone project entitled Intelligent Personal Assistant via Speech Recognition. It was installed in the laboratory classroom for evaluation. The system assessment was executed in computer subjects. The researcher used experimental approach, the respondents was group into two, the controlled and uncontrolled. The first section used the system in their laboratory class, while the other section used the actual set up in the entire duration of the Semester. The BSIT students in the first-year level were the respondents in this study. The researcher used Sloven's formula in determining the total number of respondents needed for the evaluation. The following results were based on evaluation questions related to the system that was given to the respondents.

The researcher integrated the Artificial Intelligence System in one of the laboratory classrooms in the Institute of laboratory classroom. The duration of the system testing was in the first semester in an academic year. At the end of the semester, the researcher conducted a survey to determine the acceptability of this technology. Issues and concern arise regarding the usage of the application that each student and instructor have been experienced has been take into consideration. A recommendation has been provided by the researcher in order to address the areas concern which have been identified based on the outcome of the survey. At the end of the semester, a guided questionnaire has been given to the respondents to assess the user's acceptability. All data has been collected and interpreted by the researcher.

\section{RESULT AND DISCUSSION}

The system designed to minimize the problems in the existing system and the organization will meet its specific aims. Improvement of technology is important for improving other systems of an organization like classroom management. This will be an added advantage and management of manpower based on their free time from its normal duty (Durga Prasad Mahato, 2012). The application helped to maximize the time allotted to every laboratory class since the ratio of the computer units is not equal to the number of students.

\section{A. System Implementation}

The system has been installed in the server, while the server was connected to the entire workstation in the classroom laboratory shown in figure 2. The server was managed by the faculty assigned in the ICT subject. The faculty can manipulate every computer via voice command recognition by using lapel microphone, the system has the capability to open and close the software application installed Engineering and applied technology, specifically in the IT

in every computer simultaneously, also the system can turn-on and off the light inside the classroom as well as the electric fan installed. However, the only focus of the study was the assessment on how the system manipulates the application software installed in every workstation.

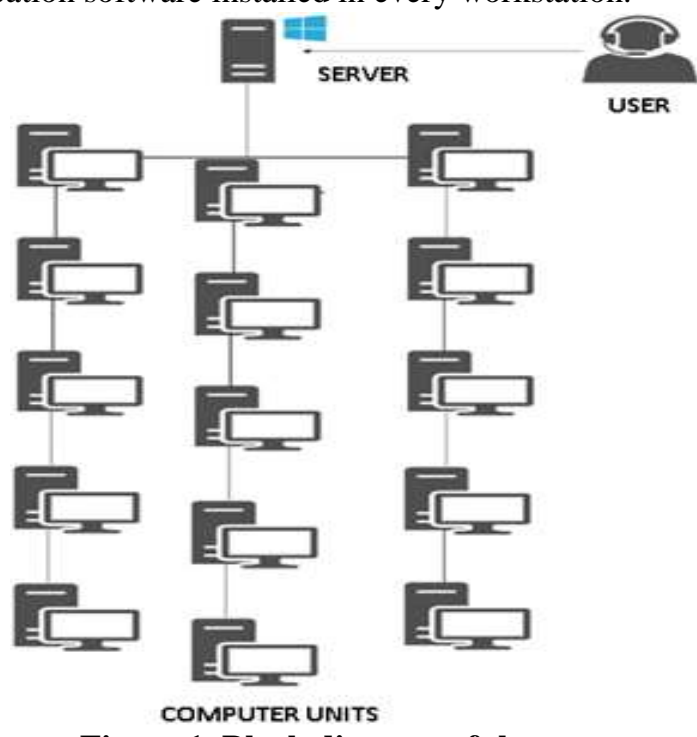

Figure 1. Block diagram of the system

\section{B. Systems Interface Design}

The graphical user interface was used to help the user to interact with the system. This will help the user to recognize the different command and functionality of the application. The interface design of the system is very simple and easy to understand. It has the list of the different command that the user can perform. On the right side of the window panel, the different command has been listed. Moreover, in the left side of the window panel, the current functionality of the system that was running has been displayed for reference. While on the middle of the module the Start, Restart, Shutdown, Enable Hardware Control and Stop button was located. This button was used to control the different workstation in the classroom laboratory.

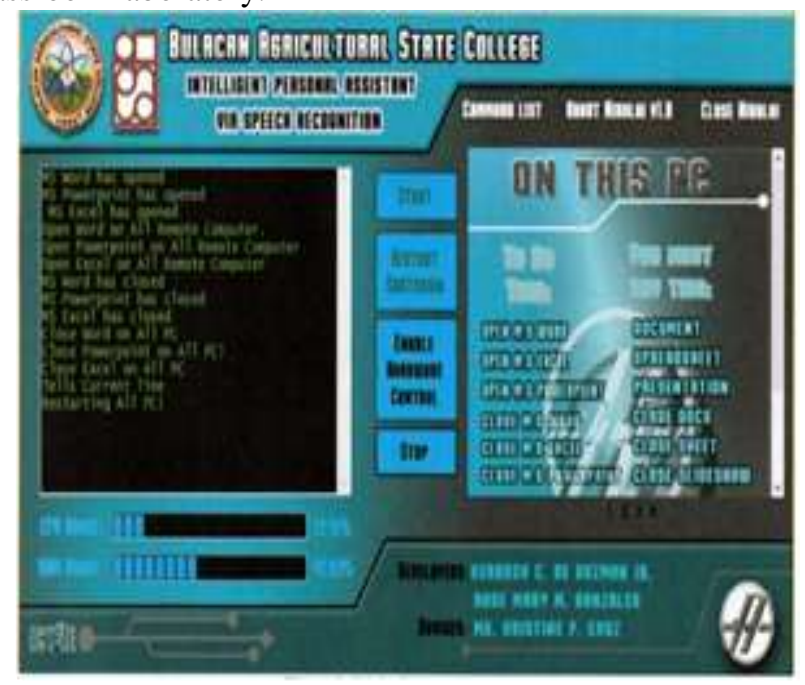

Figure 2. Interface Design of the system

C.Difficulties encountered in the existing process in managing the computer laboratory

The researcher conducted a class observation to identify the difficulties encountered in 
the existing process in managing the computer laboratory. Through observation and interview, it was found out that the usual size of every class was divided into three to four groups. Students always asked for extra time to do laboratory activities, by launching the different application needed in class, it already consumes time. Also, they could not manage their time properly due to some students keep on manipulating and surfing different applications installed in assigned computer unit which is not part of the activity given by the faculty in-charge. The faculty gave an allotted time to the students to save their work or activity, close the open applications and shutdown of the computer unit. The three (3) hours allotted to every laboratory session for every student turned into one hour, on that time allotted the preparation in every session such as opening and closing every application needed also lessen the remaining time.

By using the system, the faculty in-charge can command the AI to open or to close the application needed, and then this command will automatically be applied in the entire workstation. This functionality of the system can really lessen its time in preparing every workstation during laboratory class. It is fast to turn on and off the computer unit and can perform immediately the checking of the student's activity after every session, for it will be save in the server immediately. By this, the faculty will no longer need to go to individual student to assess their activity.

For the students, they can have equal time in performing their laboratory activities since the system will automatically turn on and off the computer units once the instructor used the voice command recognition. Also, every software application needed in every activity will be open and close automatically at the same time. It will be more convenient for the instructors who occasionally need to verify and observe the student's performance during laboratory class since every workstation was already connected to the system.

Table 1

Assessment of the Respondents on the Functionality of the System

\begin{tabular}{|c|c|c|c|}
\hline $\begin{array}{c}\text { Characteristi } \\
\text { cs }\end{array}$ & Items & AWM & $\begin{array}{c}\text { Verbal } \\
\text { Interpretati } \\
\text { on }\end{array}$ \\
\hline Suitability & $\begin{array}{c}\text { The software } \\
\text { has suitable } \\
\text { but acceptable } \\
\text { but } \\
\text { appropriate set } \\
\text { of functions in } \\
\text { accordance to } \\
\text { its system } \\
\text { objectives. }\end{array}$ & 4.08 & $\begin{array}{c}\text { Very } \\
\text { Acceptable }\end{array}$ \\
\hline Accuracy & $\begin{array}{c}\text { The software } \\
\text { provides } \\
\text { accurate } \\
\text { results. }\end{array}$ & 4.10 & $\begin{array}{c}\text { Very } \\
\text { Acceptable }\end{array}$ \\
\hline Compliance & $\begin{array}{c}\text { The software } \\
\text { addresses the } \\
\text { defined set of } \\
\text { needs. }\end{array}$ & 4.06 & $\begin{array}{c}\text { Very } \\
\text { Acceptable }\end{array}$ \\
\hline Overall Weighted Mean & 4.08 & $\begin{array}{c}\text { Very } \\
\text { Acceptable }\end{array}$ \\
\hline
\end{tabular}

Table 1 shows the result of the assessment of the system.
Based on the given result, the accuracy of the systems got the highest mean value with the average mean of 4.10 and it is interpreted as very acceptable. This means that the system provides an accurate result. However, the compliance got the lowest value with the average mean of 4.06 . The overall weighted mean of the system based on the functionality of the system was 4.08 which are interpreted as very acceptable.

Table 2

The Assessment of the Respondents on the Reliability of the System

\begin{tabular}{|c|c|c|c|}
\hline Characteristics & Items & $\begin{array}{c}\text { End } \\
\text { Userr } \\
\text { S } \\
\text { Mean }\end{array}$ & $\begin{array}{c}\text { Verbal } \\
\text { Interpretati } \\
\text { on }\end{array}$ \\
\hline & $\begin{array}{c}\text { It has the } \\
\text { ability to } \\
\text { maintain a } \\
\text { specified level } \\
\text { of } \\
\text { performance } \\
\text { in case of } \\
\text { software faults } \\
\text { or of } \\
\text { infringement } \\
\text { of its specified } \\
\text { interface. }\end{array}$ & 4.10 & $\begin{array}{c}\text { Very } \\
\text { Acceptable }\end{array}$ \\
\hline $\begin{array}{c}\text { It has the } \\
\text { capability to } \\
\text { re-establish its } \\
\text { level of } \\
\text { performance } \\
\text { and recover } \\
\text { the data } \\
\text { directly } \\
\text { affected in } \\
\text { case of failure } \\
\text { and on time } \\
\text { and effort } \\
\text { needed for it. }\end{array}$ & 3.98 & Acceptable \\
\hline Overall Weighted Mean & 4.04 & $\begin{array}{c}\text { Very } \\
\text { Acceptable }\end{array}$ \\
\hline & $\begin{array}{c}\text { Very } \\
\text { Recoverability }\end{array}$ & \\
\hline & & \\
\hline
\end{tabular}

Table 2 shows the assessment of the respondents on the reliability of the system. Based on the given result, fault tolerance has the highest mean, it was rated as 4.10. It means that the system has the ability to maintain a specified level of performance in case of software faults or of intrusion of its particular interface. While the lowest mean value was the recoverability of the system with the average mean of 3.98 . The overall weighted mean value of the system was rated as 4.04 , which is interpreted as very acceptable. 
Table 3

The Assessment of the Respondents on the Usability of the System

\begin{tabular}{|c|c|c|c|}
\hline Characteristics & Items & $\begin{array}{c}\text { End } \\
\text { User' } \\
\text { S } \\
\text { Mean }\end{array}$ & $\begin{array}{c}\text { Verbal } \\
\text { Interpretatio } \\
\text { n }\end{array}$ \\
\hline $\begin{array}{c}\text { Understandabili } \\
\text { ty }\end{array}$ & $\begin{array}{c}\text { It is easy for } \\
\text { the users to } \\
\text { reco0gnize } \\
\text { its logical } \\
\text { concept and } \\
\text { applicability. }\end{array}$ & 4.07 & $\begin{array}{c}\text { Very } \\
\text { Acceptable }\end{array}$ \\
\hline $\begin{array}{c}\text { Learnability } \\
\text { It easy for } \\
\text { the users to } \\
\text { learn its } \\
\text { application. }\end{array}$ & 4.05 & $\begin{array}{c}\text { Very } \\
\text { Acceptable }\end{array}$ \\
\hline Operability & $\begin{array}{c}\text { The software } \\
\text { is easy to } \\
\text { operate. }\end{array}$ & 4.12 & $\begin{array}{c}\text { Very } \\
\text { Acceptable }\end{array}$ \\
\hline \multicolumn{2}{|c|}{ Overall Weighted Mean } & 4.08 & $\begin{array}{c}\text { Very } \\
\text { Acceptable }\end{array}$ \\
\hline
\end{tabular}

Table 3 shows the result on the assessment of the respondents on the usability of the system. Based on the result, the operability of the system has the highest mean value with 4.12 averages which is interpreted as very acceptable. It only shows that the end users easily understand the interface and the organization of the system's functionality. The learnability has the lowest mean value of 4.05 but still, it is interpreted as very acceptable. It only means that the end users can be easily trained in accessing the system. The overall weighted mean of the usability assessment has the average mean of 4.08 and it is interpreted as very acceptable. The result shows that the system was easy to use.

Table 4

The Assessment of the Respondents on the Efficiency

\begin{tabular}{|c|l|c|c|}
\hline \multicolumn{1}{|c|}{$\begin{array}{c}\text { of the system } \\
\text { cs }\end{array}$} & $\begin{array}{l}\text { Items } \\
\text { User's } \\
\text { Mean }\end{array}$ & $\begin{array}{l}\text { Verbal } \\
\text { Interpretati } \\
\text { on }\end{array}$ \\
\hline $\begin{array}{c}\text { Time } \\
\text { behavior }\end{array}$ & $\begin{array}{l}\text { It has } \\
\text { acceptable } \\
\text { response } \\
\text { and } \\
\text { processing } \\
\text { time and } \\
\text { throughput } \\
\text { rates. }\end{array}$ & 3.85 & $\begin{array}{c}\text { Very } \\
\text { Acceptable }\end{array}$ \\
\hline $\begin{array}{c}\text { Resource } \\
\text { behavior }\end{array}$ & $\begin{array}{l}\text { It } \\
\text { consistently } \\
\text { uses enough } \\
\text { computing } \\
\text { resources } \\
\text { (memory } \\
\text { space) for } \\
\text { all its } \\
\text { function. }\end{array}$ & 4.01 & $\begin{array}{c}\text { Very } \\
\text { Acceptable }\end{array}$ \\
\hline Overall Weighted Mean & 3.93 & $\begin{array}{l}\text { Very } \\
\text { Acceptable }\end{array}$ \\
\hline
\end{tabular}

Based on the result of the assessment of the respondents as shown in table 4 , the system was evaluated as very acceptable in terms of efficiency. The highest mean value of the system was 4.01 in terms of its resource behavior. It means that the system consistently uses enough computing resources for all its functionalities. The lowest rated mean was the time behavior with the average weighted mean of 3.85 , but still interpreted as very acceptable. It only means that the system responds easily base on its time behavior. The overall weighted mean value of the system was rated as 3.93 , which is interpreted as very acceptable.

The respondents also evaluated the maintainability of the System as shown in table 5. It is categorized by its changeability, stability and testability. The changeability of the system was described as the relatively easiness to modify the software and to easily remove faults. Stability of the system was described as the deemed stable when modified. Also, the testability of the system was described as its easiness to validate with any modification in the system.

Table 5

The Assessment of the Respondents on the Maintainability of the System

\begin{tabular}{|c|c|c|c|}
\hline Characteristics & Items & $\begin{array}{c}\text { End } \\
\text { User's } \\
\text { Mean } \\
\end{array}$ & $\begin{array}{c}\text { Verbal } \\
\text { Interpretation }\end{array}$ \\
\hline Changeability & $\begin{array}{c}\text { It is } \\
\text { relatively } \\
\text { easy to } \\
\text { modify } \\
\text { the } \\
\text { software } \\
\text { or } \\
\text { remove } \\
\text { faults. }\end{array}$ & 3.76 & Very Acceptable \\
\hline Stability & $\begin{array}{c}\text { It is } \\
\text { deemed } \\
\text { stable } \\
\text { when } \\
\text { modified. }\end{array}$ & 3.65 & Very Acceptable \\
\hline Testability & $\begin{array}{l}\text { It is easy } \\
\text { to } \\
\text { validate } \\
\text { any } \\
\text { modificat } \\
\text { ion } \\
\text { made. }\end{array}$ & 3.96 & Very Acceptable \\
\hline \multicolumn{2}{|c|}{ Overall Weighted Mean } & 3.79 & Very Acceptable \\
\hline
\end{tabular}

From the result given in Table 5, in terms of changeability, stability and testability, the system is very acceptable. Based on the overall weighted mean result, the system can be easily maintained. Overall, the respondents evaluated the system as very acceptable with a mean rating of 3.79. This implied that the respondents are amenable that the system can easily edit and update the information and the system can be easily maintained. 
Table 6

Summary of Mean Performance Evaluation of the respondents of the system

\begin{tabular}{|c|c|c|}
\hline Items & Mean & Interpretation \\
\hline Functionality & 4.08 & Very Acceptable \\
\hline Reliability & 4.04 & Very Acceptable \\
\hline Efficiency & 3.93 & Very Acceptable \\
\hline Usability & 4.08 & Very Acceptable \\
\hline Maintainability & 3.79 & Very Acceptable \\
\hline $\begin{array}{c}\text { Overall Weighted } \\
\text { Mean }\end{array}$ & 3.98 & Very Acceptable \\
\hline
\end{tabular}

Based on the evaluation result, functionality and the usability got the same highest rating of 4.08, which means that the end users found out that the developed system reach its objectives in terms of its intended purpose and the system is very useful to them. While the maintainability indicator got the lowest rating of 3.79 which only means that the respondents are not experts in terms of maintaining the system, but that issue can cope up by giving them enough training and continuous support while using the system.

\section{CONCLUSION}

By implementing the system, every faculty can save time, effort and energy in managing the laboratory. Different task and activities like launching and/or terminating specific application software installed in the server and in every work station will be done automatically using voice command recognition. The system is very effective in minimizing the time in preparation during laboratory class which is beneficial not only for the students but most especially for the Faculty who teach the different computer related subjects. Based on the result of the survey, each functionalities of the system were highly accepted by the respondents. This only shows that different technology innovations and applications like Artificial Intelligence system will be a great help not only for the faculty in-charge but most probably for schools to improve its quality service for its clientele. Finally, for further studies, the researchers like to study the vulnerabilities of the system in terms of its data security since all computers in each workstation have been connected. Also, to improve the developed system, it would be better to consider a module that will automatically detect an intruder on the network, to secure the data in each workstation. The future researchers may include chat box to maximize the usage of the system. Newer and more sophisticated approach for integration and data collections are essential to enhance the system. Finally, the researcher can say that this system will not only automate the process but also save valuable time in managing the laboratory class, which can be well utilized by the institute.

\section{REFERENCES}

1. M. Ji, "Research on the Dimension Management of Computer Lab," International Conference on Logistics Engineering, Management Computer Science (LEMCS2015), 2015.

2. Panel, Fang,Wanga and Milena "How can the Web help build customer relationships"V. A. P. Yulia Vertakova,
"Problems of sustainable development worldwide and public policies for a green economy," Інститут трансформації суспільства, по. 7-8, pp. 4-10, 166/2017.

3. B. Beek ; E. Neuberg ; D. Hodge"An assessment of the technology of automatic speech recognition for military applications"Unilever Philippines, "Facebook," 16 march $2019 . \quad$ [Online]. Available: https://www.facebook.com/BeatPlasticPollutionPH/posts /540435906363837.

4. Dough, Beeferman,Francoise Beaufays, bill Byrne" Your Word is my Command": Google Search by Voice"

5. Vicki St. John, Voice Recognition system in navigating the internet

6. Michael K. Davis, Joseph Miglietta, Douglas Holt,"Speech recognition and transcription among users having heterogeneous protocols"

7. Patseer,"Voice Recognition- Controlling mobile devices using voice commands"

8. Cheong Soo Yee and abdul Manan ahmad, "Malay Language Text Independent Speaker Verification using NN-MLP classifier with MFCC, 2008 international Conference on Electronic Design".

9. Shikha Gupta1 ,Mr.Amit Pathak2 ,Mr.Achal Saraf3,"A study on speech recognition system: a literature review"

10. NishthaMadaan, Mohd AbdulAhad, Sunil M.Sastry,"Data integration in IoT ecosystem: Information linkage as a privacy threat"

11. LI Shi-guo (Jiangnan University,Wuxi 214122,China),"A Study on Intelligent Things in the Internet of Things"

12. Liu Cheng Jiang Wen-ying (Beijing Telecom Planning \& Designing Institute Co., LTD, Beijing, 100048, China),"Investigation of Operation Platform of the Internet of things"

13. JIAO Ya-bing, "Building MIS for Internet of Things Based on RFID/EPC Technologies"

14. ZHANG Zhi-dong1,LI Hai-ying2, "Study on the Impacts of Internet of Things Era on Industrial Design

\section{AUTHORS PROFILE}

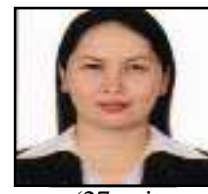

Kristine C. Buenaventura IT INSTRUCTOR

Institute of Engineering and Applied Technology Bulacan Agricultural State College (BASC)

(27 units earned) Masters in Information Technology

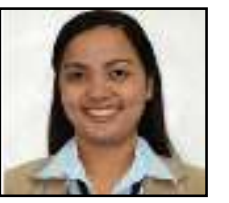

Ma. Melanie Ablaza-Cruz

IT INSTRUCTOR

Doctor of Information Technology

Publications: 1) Predicting Student's Board Examination Performance using Classification Algorithms, ICSCA 2018. ACM New York, NY, USA

C)2018

Published by the Association for Computing Machinery. Copyright ( 2019 ACM, Inc.

2) Assessing the impact of e-learning system of higher education institution's instructors and students

Published under license by IOP Publishing Ltd

IOP Conference Series: Materials Science and Engineering, Volume 482 , Number 1 